\title{
Design and Optimization of Straddle Carrier Trolley Gate
}

\author{
Rajesh Kumar", A. B. Gaikwad \\ ${ }^{\#}$ Department of Mechanical Engineering,Dr. D. Y. Patil School of engineering, Charholi(Bk), Pune- \\ 412105, Savitribai Phule Pune University.
}

\begin{abstract}
Straddle carriers help optimize terminal productivity by decoupling waterside and landside operations. The speed, reach and flexibility of straddle carriers allow terminals to use a single type of equipment for all container operations. Kalmar straddle carriers can handle loads of up to 60 tonnes and stack containers up to 4-high. Kalmar straddle carrier is built on a heritage of over 70 years. To date over 5000 units have been manufactured. The first fully automated terminal are using Kalmar Autostrada was open in Brisbane, Australia in 2005. Kalmar develops energy-efficient, safe and intelligent machinery and automation solutions at its Technology and Competence Centre in Tampere, Finland. The Centre is a unique research facility that simulates port operations and includes an extensive testing area for new equipment and solutions. There are different type of straddle carrier are using to handling the container on the port. In these there are different type of components are assembled in this vehicle.Here we are considering one of the important part of the straddle carrier which is called gate frame. This gate is important related to the safety for the people who are working there.
\end{abstract}

Keywords: Gate design, Gate optimization, Bolt calculation, Finite element approach, experimental analysis.

\section{Introduction}

There are different type of straddle carrier are using to handling the container on the port. In these there are different type of components are assembled in this vehicle.

Here we are considering one of the important parts of the straddle carrier which is called gate. This gate is important related to the safety for the people who are working there on the different platforms, 4 to 5 selfclosing gates should be installed to prevent people from falling down. These gates need to withstand a force of $250 \mathrm{Kg}$ both in horizontal as in vertical direction without plastic deforming. This needs to be proven by calculation notes provided by the manufacturer.

The purpose of this research is to increase the load capacity of gate. For this there is requirement of modification in the shape of gate geometry. Thus gate is modified and check for the stress and vibration analysis. After doing modifications in the geometry and its iterations for the analysis, we will get the required results. As per the requirement, the simulation of a model should be done using software. For that we follow two basic steps as modeling and then analysis. We do modeling in CATIA V5 and analysis in 'ANSYS'. The main part of this project is to do analysis using 'ANSYS'. For this finite element analysis is required to study. The main motivation behind the work was to go for FEA of this structure. The gate structure is taken for staticanalysis.Since last decade advent of powerful finite element analysis (FEA) have proven good tool to analyses the problem. The Various complicated geometries can be analyzed by FEAinstead of doing analytical calculations. Optimized meshing and accurate simulation of boundary conditions along with the ability to apply complex load, provided by various FEM packages have helped the designer to carry vibration analysis with the investigation of critical stresses and contact stresses. FEM is used to find critical locations and quantitative analysis of stress distribution and deformed shape under loads. However detailed modeling and specialized knowledge of FEM theory are indispensable to perform these analyses with high accuracy. They also require complicated meshing strategies. Simulations of actual boundary conditions to equivalent FE boundary conditions have to be done carefully because a wrongly modeled boundary condition leads to erroneous results. The solution of such large scale FEM problem requires both large memory and disc space as computing resources.

\section{Literature Review}

Self-closing gate is used in the straddle carrier. It is used for the safety purpose of operator. This product is under the Cargotec Company. They have developed the process of this gate structure. But the initially load carrying capacity was less for the structure. Hence company needs to increase the load capacity of the gate structure [1].

Americannational standard (ANSI/ASSE Z359.14-2014) safety requirements for self-retracting devices for personal fall arrest \& Rescue System. This standard establishes requirements for SRDs intended for use in personal fall arrest or rescue systems for authorized persons within the capacity range of 59 to $141 \mathrm{~kg}$.[2] 
American national standard (ANSI/ASSE Z359.4-2013) safety requirements for assisted-rescue, subsystems and components. Establishes requirements for the performance, design,marking, qualification, instruction, training, use, maintenance and removal from service of connectors, harnesses, lanyards, anchorage connectors, winches/hoists, descent control devices [3]

\section{Problem Statement And Objective}

Design and optimization of self-closing gate for straddle carrier and improving the strength of gate and provide safety to the operator". The Existing gate was not able to provide the strength for safety of operator .The straddle Carrier Company has decided to change the design with analysis of safety gate. Now for new design of gate they increase the load capacity of the gate. Now the gate is designed in a category of self-closing gate. For this project we will consider different type of arrangements for the gate installation like bolted arrangement or bearing arrangement.

\section{A. The dimensions of gate structure}

\section{Theoretical Calculation}

Table IDimensions of Gate

\begin{tabular}{|l|l|}
\hline Properties & Dimensions \\
\hline Outer diameter of a circular pipe & $33.7 \mathrm{~mm}$ \\
\hline Inner diameter of a circular pipe & $28.5 \mathrm{~mm}$ \\
\hline Thickness & $2.6 \mathrm{~mm}$ \\
\hline Dimension of rectangular pipe & $40 * 34 \mathrm{~mm}$ \\
\hline Thickness of rectangular pipe & $3 \mathrm{~mm}$ \\
\hline Bolt size & $\mathrm{M} 16$ \\
\hline Maximum vertical load $(\mathrm{P})$ & $2500 \mathrm{~N}$ \\
\hline
\end{tabular}

B.The material properties of steel

The material used for this structure is steel S235 JR.

Table IIMaterial Properties

\begin{tabular}{|l|l|}
\hline Material & S235JR \\
\hline Young's modulus & $2.1 \mathrm{e} 5 \mathrm{MPa}$ \\
\hline Poisson's ratio & 0.3 \\
\hline Density & $7.850 \times 10-3$ tons $/ \mathrm{mm} 3$. \\
\hline Yield strength & $355 \mathrm{MPa}$ \\
\hline
\end{tabular}

So, first we have to find out deflection forexisting and modifiedGate model.

\section{Deflection of existing gate model}

The basic principal point for this structure is to decrease the permanent deflection. For this these are following terms and calculation process to calculate the deflection.

Let,

O.D of circular pipe $=33.7 \mathrm{~mm}$

I.D of circular pipe $=28.5 \mathrm{~mm}$

Thickness of pipe $(\mathrm{T})=2.6 \mathrm{~mm}$

Pipe effective length in horizontal direction $=400 \mathrm{~mm}$

Pipe effective length in vertical direction $=300 \mathrm{~mm}$

For circular hollow cross section:

I $($ Area moment of inertia $)=\pi / 64\left[\left(\mathrm{D}^{4}\right)-\left(\mathrm{d}^{4}\right)\right]$

$$
\begin{aligned}
& =.05\left[\left(33.7^{4}\right)-\left(28.5^{4}\right)\right] \\
& =30927 \mathrm{~mm}^{4}
\end{aligned}
$$

Stiffness in $\mathrm{X}$ direction $=\mathrm{K}_{\mathrm{x}}=\mathrm{K}_{1}, \mathrm{~K}_{3}$

Stiffness in $\mathrm{Y}$ direction $=\mathrm{K}_{\mathrm{y}}=\mathrm{K}_{2}$

$\mathrm{K}_{\mathrm{x}}=(3 \times \mathrm{EI}) / \mathrm{L}^{3}$

$=(3 \times 210000 \times 30927) / 4003$

$=304.44 \mathrm{Nmm}$

$\mathrm{K}_{\mathrm{y}}=\mathrm{AE} / \mathrm{L}$

$=(254 \times 210000) / 300$

$=177820.4 \mathrm{Nmm}$

$\mathrm{K}_{12}=\left(1 / \mathrm{k}_{1}\right)+\left(1 / \mathrm{k}_{2}\right)$

$=\left[\left(\mathrm{K}_{1}+\mathrm{K}_{2}\right) / \mathrm{K}_{1} \times \mathrm{K}_{2}\right]$

$=[(304.44+177820.4) /(304.44 \times 177820.4)]$ 
$=303.9 \mathrm{Nmm}$

$\mathrm{K}_{123}=\mathrm{K}_{3}+\mathrm{K}_{12}$

$=304.44+303.9$

$=608.35 \mathrm{Nmm}$

$\mathrm{K}_{\text {equivalent }}=\mathrm{K}_{123}$

$\mathrm{K}_{\text {equivalent }}=608.35 \mathrm{Nmm}$

Deflection $(\delta)=$ Force/ Stiffness

$=2500 / 608.35$

Deflection $(\delta)=\mathbf{4 . 1 0 9} \mathrm{mm}$

\section{Deflection of modified gate model}

The basic principal point for this structure is to decrease the permanent deflection. For this these are following terms and calculation process to calculate the deflection.

Let,

O.D of circular pipe $=33.7 \mathrm{~mm}$

I.D of circular pipe $=28.5 \mathrm{~mm}$

Thickness of pipe $(\mathrm{T})=2.6 \mathrm{~mm}$

Pipe effective length in horizontal direction $=400 \mathrm{~mm}$

Pipe effective length in vertical direction $=300 \mathrm{~mm}$

For circular hollow cross section:

I $($ Area moment of inertia $)=\pi / 64\left[\left(\mathrm{D}^{4}\right)-\left(\mathrm{d}^{4}\right)\right]$

$=(.05)\left[\left(33.7^{4}\right)-\left(28.5^{4}\right)\right]$

$=30927 \mathrm{~mm}^{4}$

Stiffness of the structure ( K):

Stiffness in $X$ direction $=K_{x}=K_{1}, K_{3} \& K_{5}$

Stiffness in $\mathrm{Y}$ direction $=\mathrm{K}_{\mathrm{y}}=\mathrm{K}_{2} \& \mathrm{~K}_{4}$

$\mathrm{K}_{\mathrm{x}}=(3 * \mathrm{EI}) / \mathrm{L}^{3}$

$=(3 * 210000 * 30927) / 400^{3}$

$=304.44 \mathrm{Nmm}$

$\mathrm{K}_{\mathrm{y}}=\mathrm{AE} / \mathrm{L}$

$=(254 * 210000) / 300$

$=177820.4 \mathrm{Nmm}$

$\mathrm{K}_{12}=\left(1 / \mathrm{k}_{1}\right)+\left(1 / \mathrm{k}_{2}\right)$

$=\left[\left(\mathrm{K}_{1}+\mathrm{K} 2\right) / \mathrm{K}_{1} \cdot \mathrm{K}_{2}\right]$

$=[(304.44+177820.4) / 304.44 * 177820.4]$

$=303.9 \mathrm{Nmm}$

$\mathrm{K}_{123}=\mathrm{K}_{3}+\mathrm{K}_{12}$

$=304.44+303.9$

$=608.35 \mathrm{Nmm}$

$\mathrm{K}_{14}=\left[\left(1 / \mathrm{K}_{123}\right)+\left(1 / \mathrm{K}_{4}\right)\right]$

$=\left[\left(\mathrm{K}_{4}+\mathrm{K}_{123}\right) / \mathrm{K}_{4} * \mathrm{~K}_{123}\right]$

$=[(177820.4+608.35) /(177820.4 * 608.35)]$

$=606.3 \mathrm{Nmm}$

$\mathrm{K}_{\text {equivalent }}=\mathrm{K}_{5}+\mathrm{K}_{14}$

$=304.44+606.3$

$=910.7 \mathrm{Nmm}$

Deflection $(\delta)=$ Force/ Stiffness

$=2500 / 910.7$

$=\mathbf{2 . 7 4 5} \mathrm{mm}$ 
E. Stress criteria:

Sut $=$ Ultimate tensile strength of material

$=510 \mathrm{Mpa}$

$\mathrm{Su}=$ Yield strength of material N/mm $\mathrm{m}^{2}$

$=355 \mathrm{Mpa}$

$\mathrm{Sy}=$ Working yield strength of material $\mathrm{N} / \mathrm{mm}^{2}$

$=235 \mathrm{Mpa}$

Fos $($ Factor of safety $)=[\mathrm{Su} / \mathrm{Sy}]$

$$
\begin{aligned}
& =(355 / 235) \\
& =1.5
\end{aligned}
$$

\section{$F$. Natural frequency of structure:}

$K=$ Equivalent stiffness of structure $=910.7 \mathrm{Nmm}$

$\mathrm{M}=$ Mass of the structure $=10 \mathrm{~kg}$

$$
\begin{gathered}
\mathrm{K}=91037 \mathrm{~N} / \mathrm{mm} \\
\omega_{\mathrm{n}}=\sqrt{\frac{\mathrm{K}}{\mathrm{m}}} \\
\omega_{\mathrm{n}}=\sqrt{\frac{910.7}{10}} \\
\omega_{\mathrm{n}}=91.07 \mathrm{rad} / \mathrm{sec} \\
f_{n=\frac{\omega_{n}}{2 \pi}} \\
\boldsymbol{f}_{\boldsymbol{n}}=\mathbf{2 . 0} \boldsymbol{H z}
\end{gathered}
$$

\section{F. Bolt Calculation:}

These are the following situation for the bolt calculation of Gate model

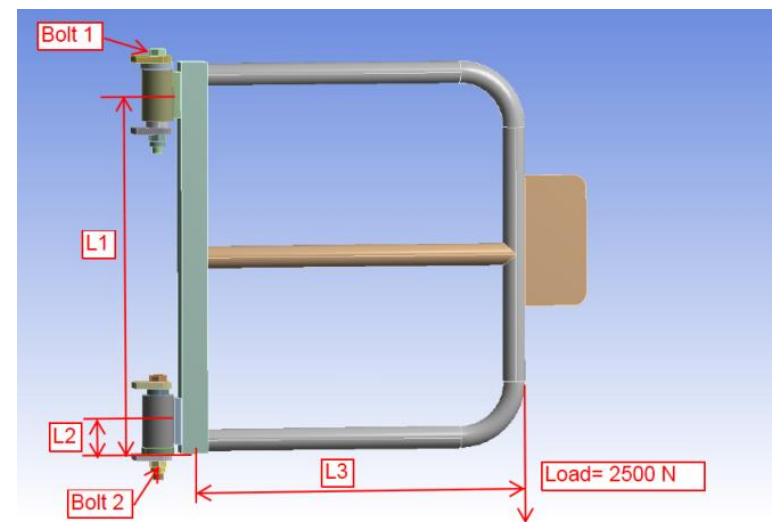

Given data for bolt calculation is as follows:

Bolt size - M16

Bolt grade -8.8

Load $-2500 \mathrm{~N}$

$\mathrm{L}_{1}=500 \mathrm{~mm}$

$\mathrm{L}_{2}=100$

$\mathrm{L}_{3}=500 \mathrm{~mm}$

In this case bolts are subjected to direct shearing load by both bolts.

Therefore direct shear load on each bolt

Where $\mathrm{n}$ is number of bolts.

$$
\mathrm{Ws}=\mathrm{W} / \mathrm{n}
$$


$=12262.5 \mathrm{~N}$

$$
\mathrm{Ws}=0.25 \times 1000 \times \frac{9.81}{2}
$$

$=12.26 \mathrm{KN}$

Each bolt will experience a different load which also depends up on the distance from the extreme load distance Let $\mathrm{W}$ be the load in a bolt per unit distance due to the turning effect of bracket and $\mathrm{W}_{1}$ and $\mathrm{W}_{2}$ be the loads on both bolt at distance $\mathrm{L}_{1}$ and $\mathrm{L}_{2}$

Load on each bolt at distance $\mathrm{L}_{1}$

$\mathrm{W}_{1}=\mathrm{w} \times \mathrm{L}_{1}$

And moment of this load about extreme length

$\mathrm{M}_{1}=\mathrm{w} \times \mathrm{L}_{1} \times \mathrm{L}_{1}$

$\mathrm{M}_{1}=\mathrm{w} \times\left(\mathrm{L}_{1}\right)^{2}$

Similarly,

$$
\mathrm{M}_{2}=\mathrm{w} \times\left(\mathrm{L}_{2}\right)^{2}
$$

Hence total moment of the load on the bolts about extreme length

$\mathrm{M}=4 \mathrm{w}\left(\mathrm{L}_{1}\right)^{2}+4 \mathrm{w}\left(\mathrm{L}_{2}\right)^{2}$

Also the moment due to the load $2500 \mathrm{~N}$ about extreme length

$\mathrm{M}=\mathrm{W} \times \mathrm{L}$

From equation (3.16) and (3.17)

$\mathrm{W} \times \mathrm{L}=\mathrm{W} \times\left(\mathrm{L}_{1}\right)^{2}+\mathrm{w} \times\left(\mathrm{L}_{2}\right)^{2}$

$\mathrm{W}=(\mathrm{W} \times \mathrm{L}) / 4\left[\left(\mathrm{~L}_{1}\right)^{2}+\left(\mathrm{L}_{2}\right)^{2}\right.$

$\mathrm{W}=(0.25 \times 1000 \times 9.81 \times 500) /[(500) 2+(100) 2]$

$=4.80 \mathrm{~N} / \mathrm{mm}$

It may be noted that the most heavily loaded bolts are those which are situated at the greatest distance from tilting edge. In this case, the bolts at distance L1 are heavily loaded

Hence, tensile load on each bolt at distance L1

$\mathrm{Wt}_{1}=\mathrm{w} \times \mathrm{L}_{1}$

$=4.80 \times 500$

$=2400 \mathrm{~N}$

$=2.4 \mathrm{KN}$

Since the bolts are subjected to shear load and tensile load therefore

Equivalent tensile load,

$=1 / 2[2.4+\sqrt{ }[(2.42)+4(12.262)]$

$$
\mathrm{Wte}=1 / 2\left[\mathrm{Wt}+\sqrt{[}\left[\mathrm{Wt}^{2}\right)+4\left(\mathrm{Ws}^{2}\right)\right]
$$

$=13.518 \mathrm{KN}$

Here equivalent tensile load $=13.518 \mathrm{KN}$

For M16 bolt, Stress area is $157 \mathrm{~mm}^{2}$

Therefore,

Equivalent tensile stress $=$

$\sigma_{\text {teqv }}=(13.518 \times 1000) / 157$

$=86 \mathrm{MPa}$

Equivalent shear load,

$$
\begin{aligned}
& \qquad \text { Wte }=1 / 2\left[\sqrt{ }\left[\left(\mathrm{Wt}^{2}\right)+4\left(\mathrm{Ws}^{2}\right)\right]\right. \\
& =1 / 2[\sqrt{ }[(2.42)+4(12.262)] \\
& =12.32 \mathrm{KN}
\end{aligned}
$$

Here equivalent shear load $=12.32 \mathrm{KN}$

Equivalent shear stress $=$

$\sigma_{\text {seqv }}=(12.32 * 1000) / 157$

$$
=78 \mathrm{MPa}
$$



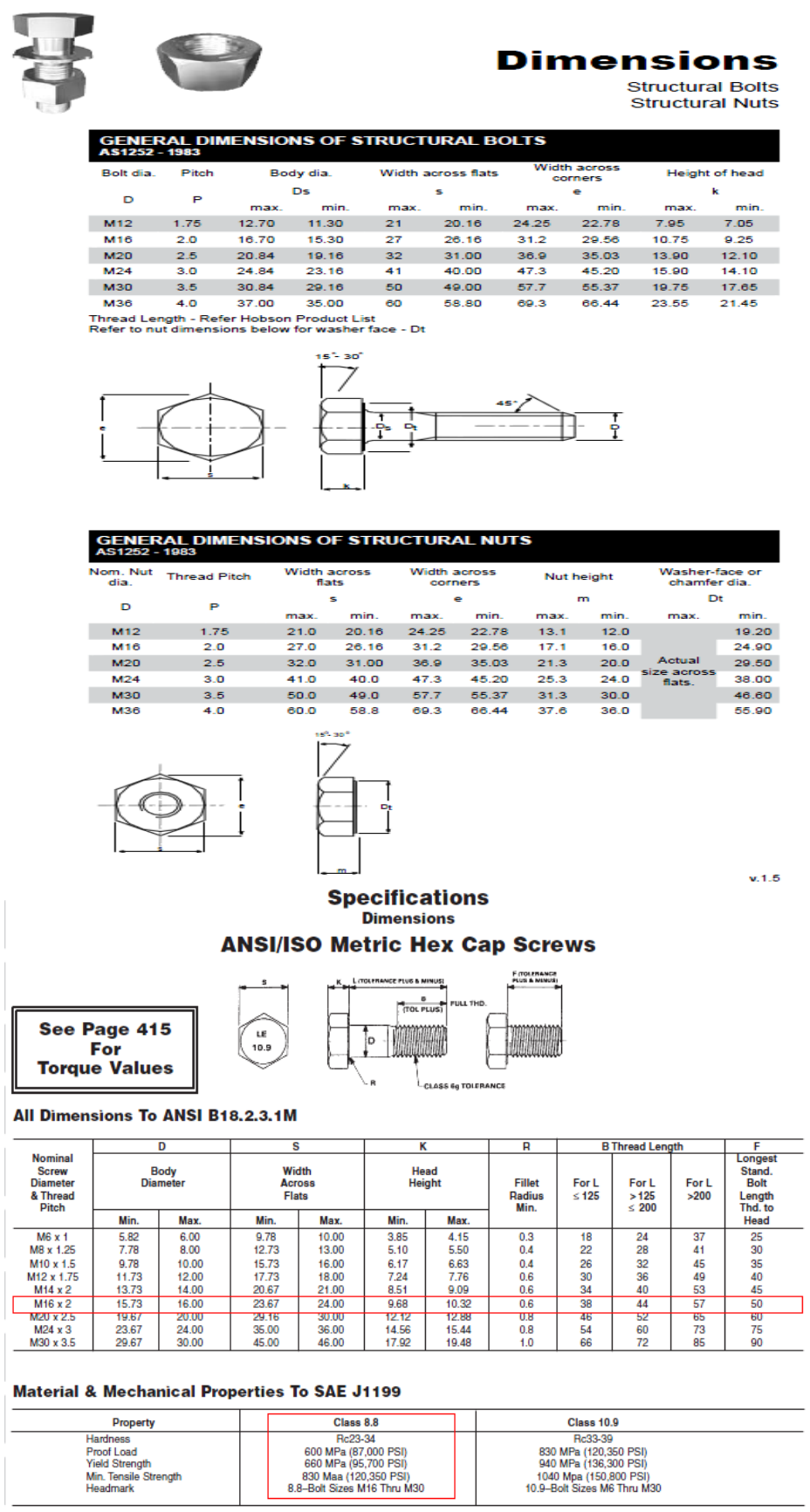

Metric Class 12.9 Socket Head Cap Screws

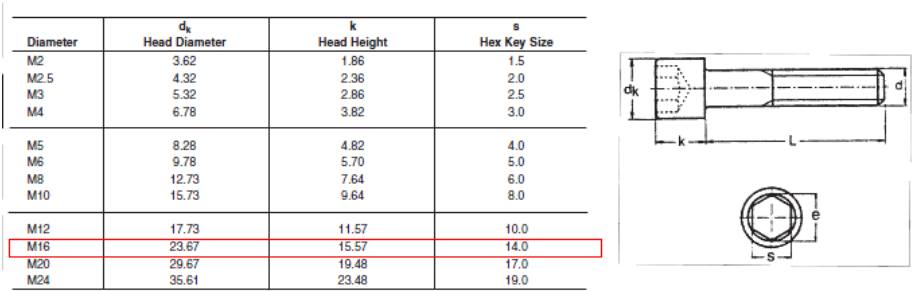

Comparison of bolt calculation has been done in next chapter Finite Element Analysis. 


\section{Finite Element Analysis}

Static stress analysis of gate of straddle carrier is performed by ANSYS 16.1 software to determine the stress and deflection values of both Existing and Modified structure.

\section{A. Solid modeling of gate.}

Solid model of gateis created by CATIA software which makes modeling so easy and user friendly.

Fig.1shows a solid model of Existing and Modified Gate.
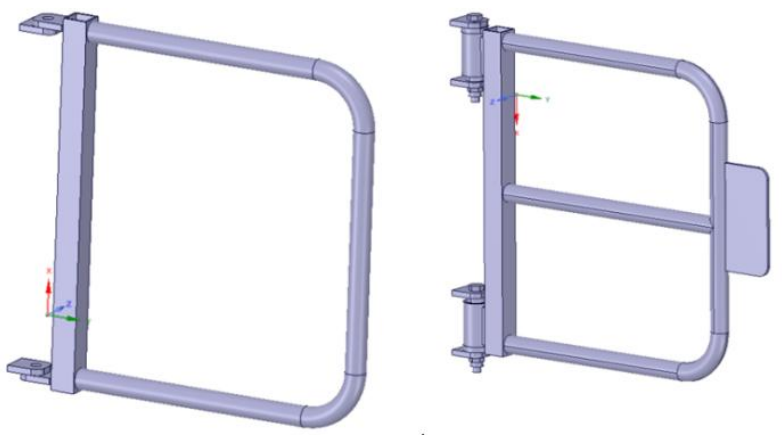

Fig.1 Existing and Modified Solid model of Gate

\section{B. Stress Analysis}

Solid model of gate is created by CATIA software then this model is saving in IGES format and export into the FEA software ANSYS 16.1. The existing and modified structure is analyzed in FEA software. Following steps are used to find analysis results,

1) Material properties

2) Connections

3) Meshing.

4) Loads and boundary condition.

5) Results

\section{Contact and Mesh generation}

The contacts defined for both Existing and Modified model is bonded. The meshing of existing and modified Gate modelhas done in ANSYS 16.1(Workbench) software.

Fig. 2 shows thecontacts in modified gate structure.

Fig. 3 and 4 shows themeshing of Existing and modified Gate model respectively.

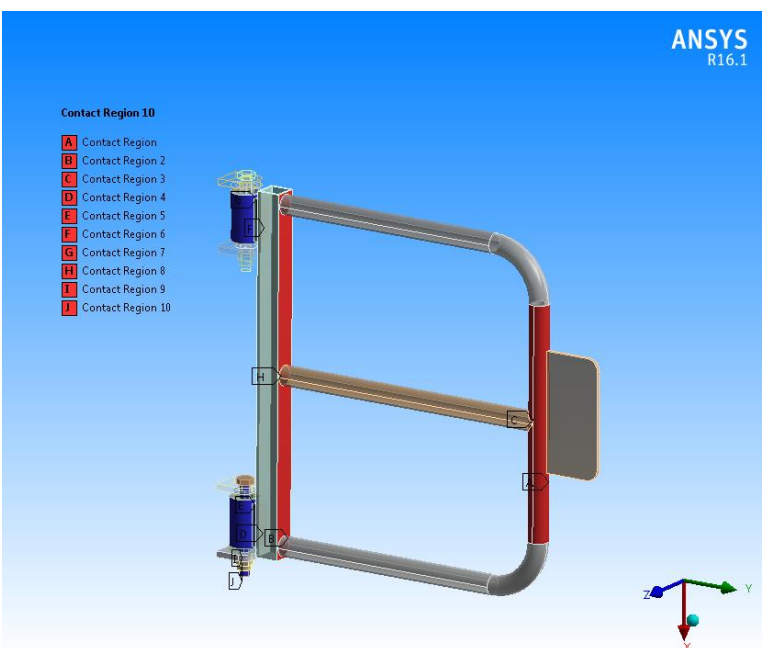

Fig. 2 Bonded connection of modified gate 


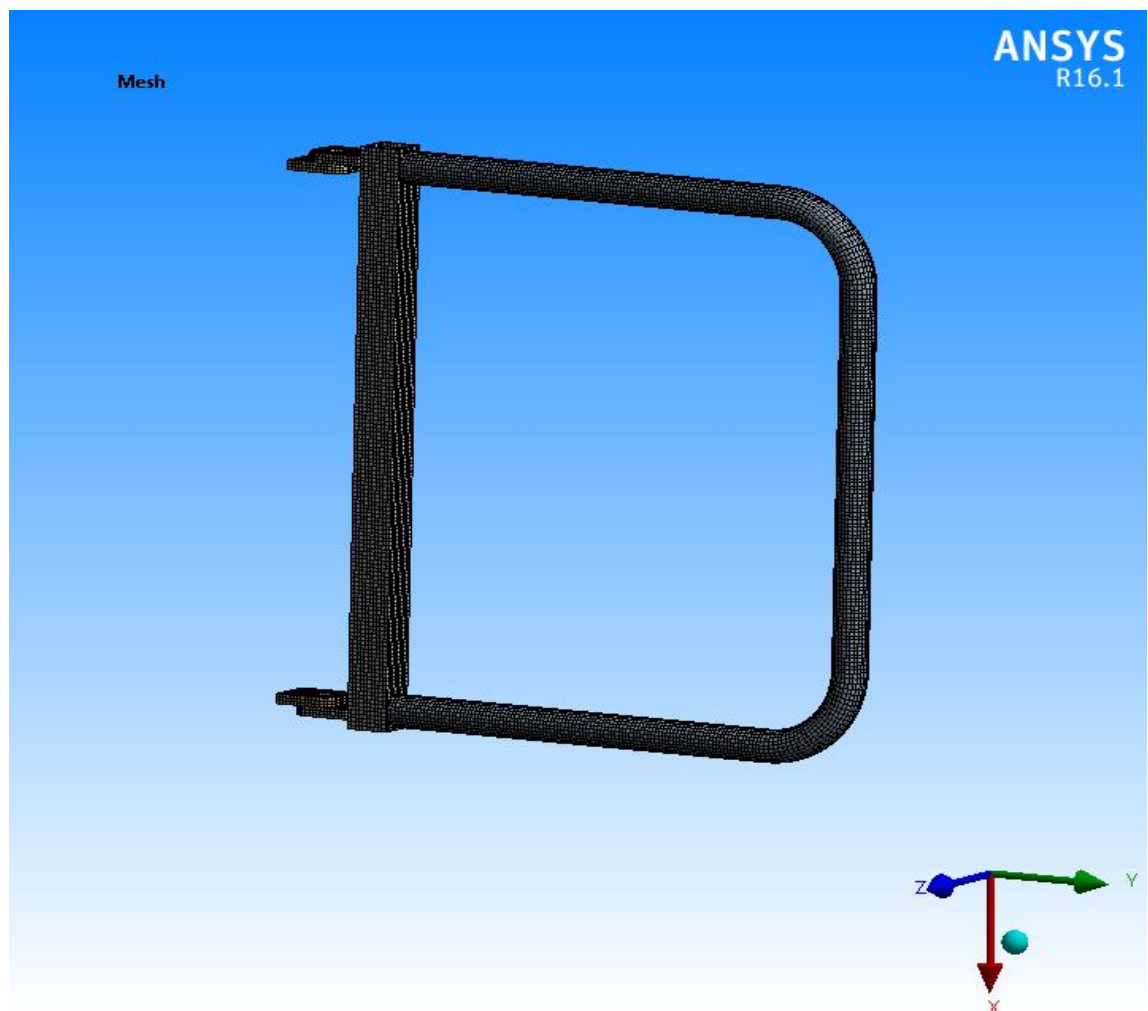

Fig. 3 meshing of existing gate

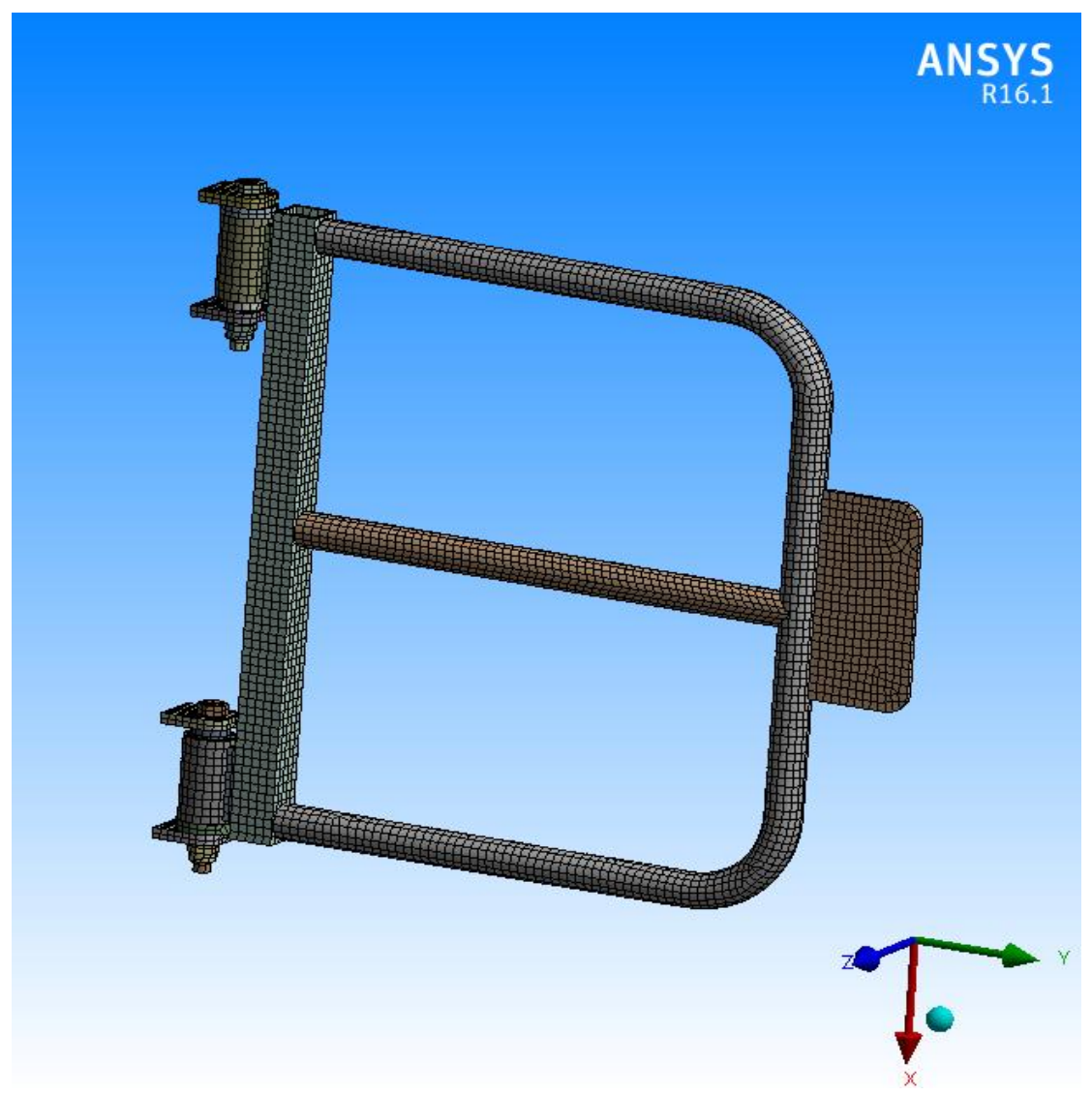

Fig. 4 meshing of modified gate

\section{Loads and Boundary Conditions}

Static structural analysis was performed to determine equivalent (von-misses) stresses and total deformation of existing and modified Gate model by ANSYS software. For this above boundary conditions are 
used: Fixed support and Force. Existing and modified Gate model is fixed as shown in fig.7 and fig.8 Maximum load is $2500 \mathrm{~N}$. So, $2500 \mathrm{~N}$ load was applied on vertical direction of structure in downward direction.

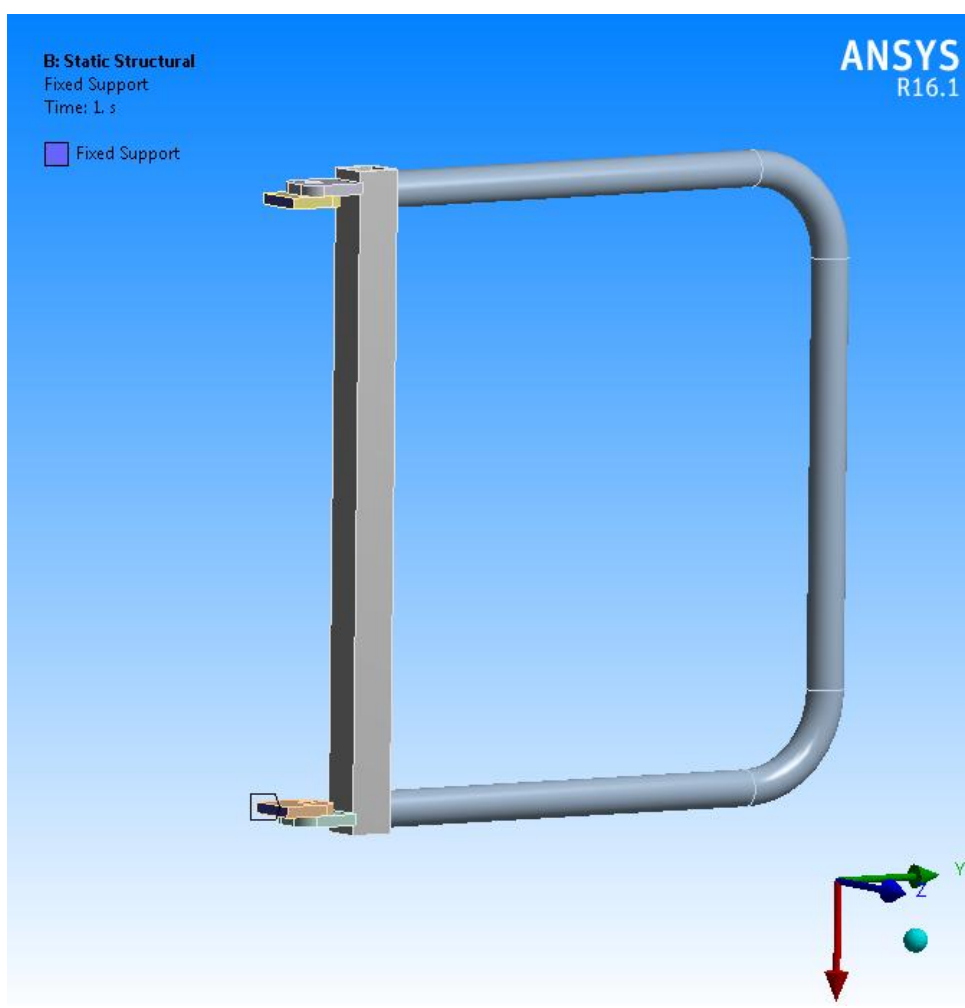

Fig. 5 Fixed supports for Existinggate

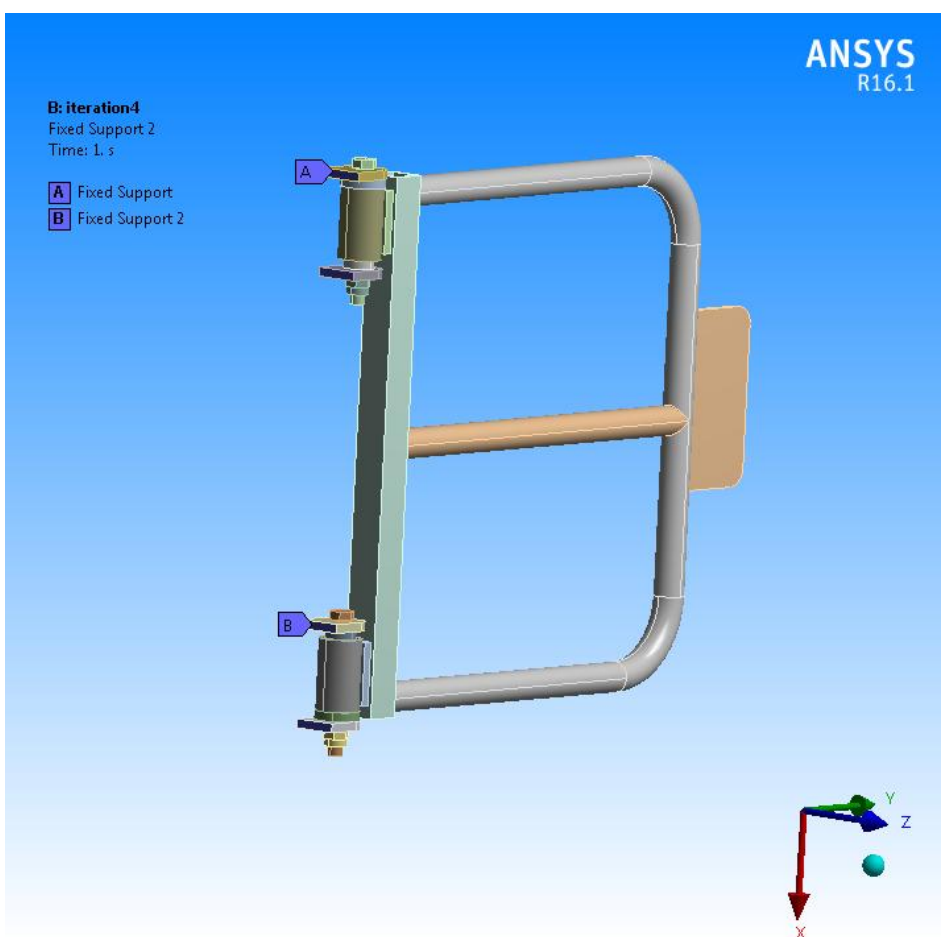

Fig. 6 Fixed supports for Modified Gate 


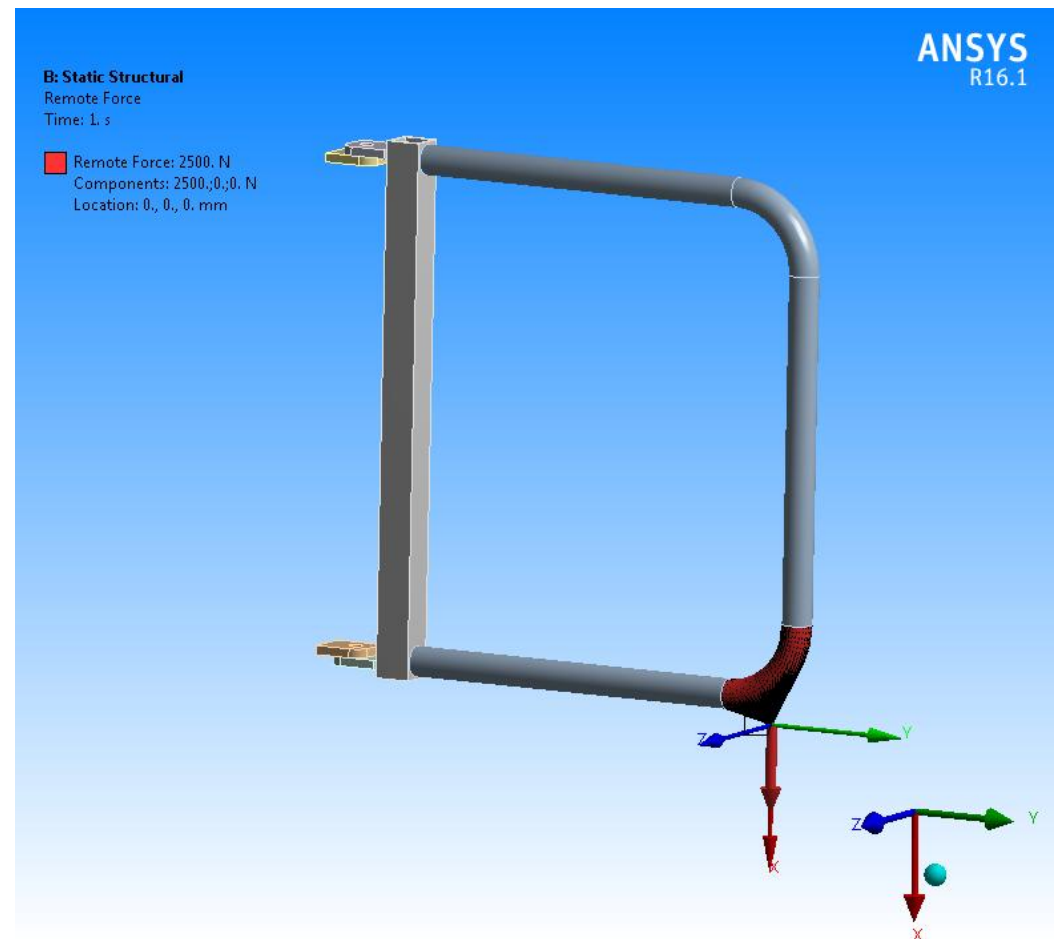

Fig. 7loading on existing gate

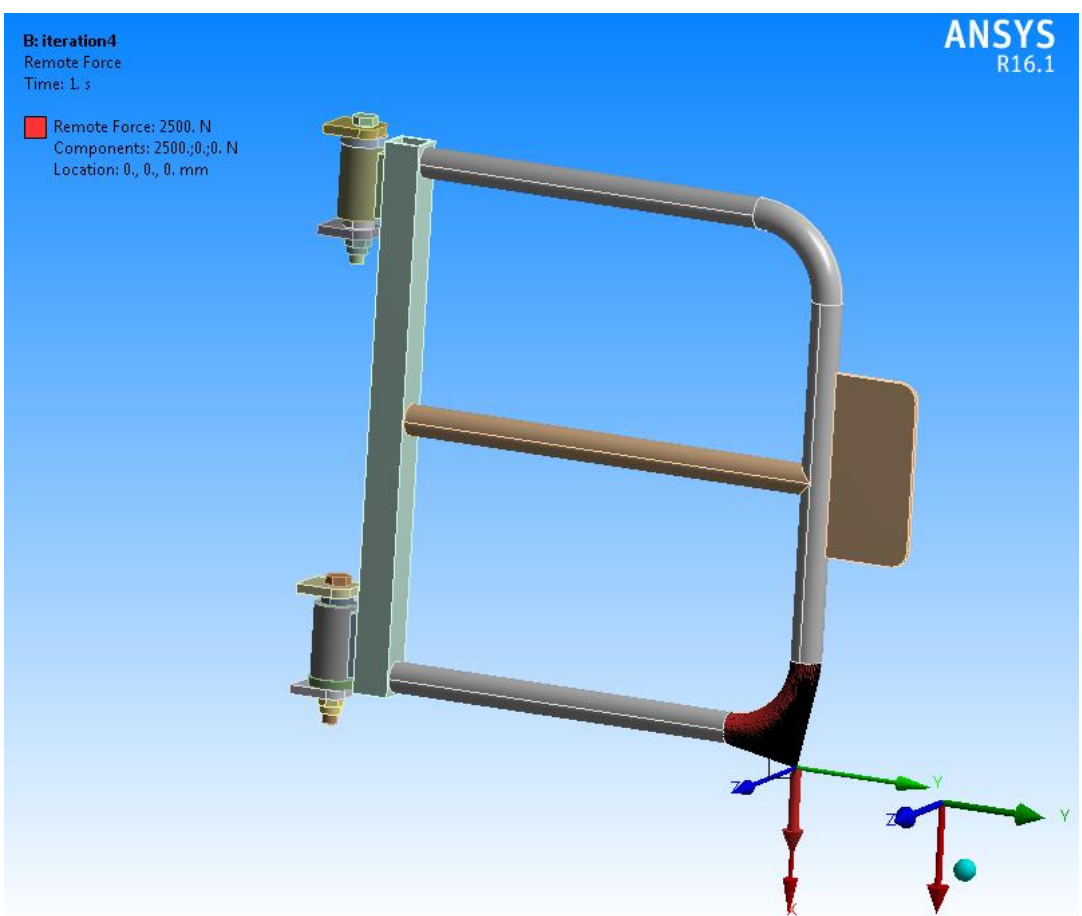

Fig. 8loading on modified gate

\section{E. Analysis: Equivalent (von-mises) Stress and total deformation of Existing gate model}

The fig.9 shows the stress value of the modified gate structure. Stress obtained from ExistingGate structure is $260 \mathrm{MPa}$ and Fig.10 shows deformation of existing gate model is $3.8 \mathrm{~mm}$. 


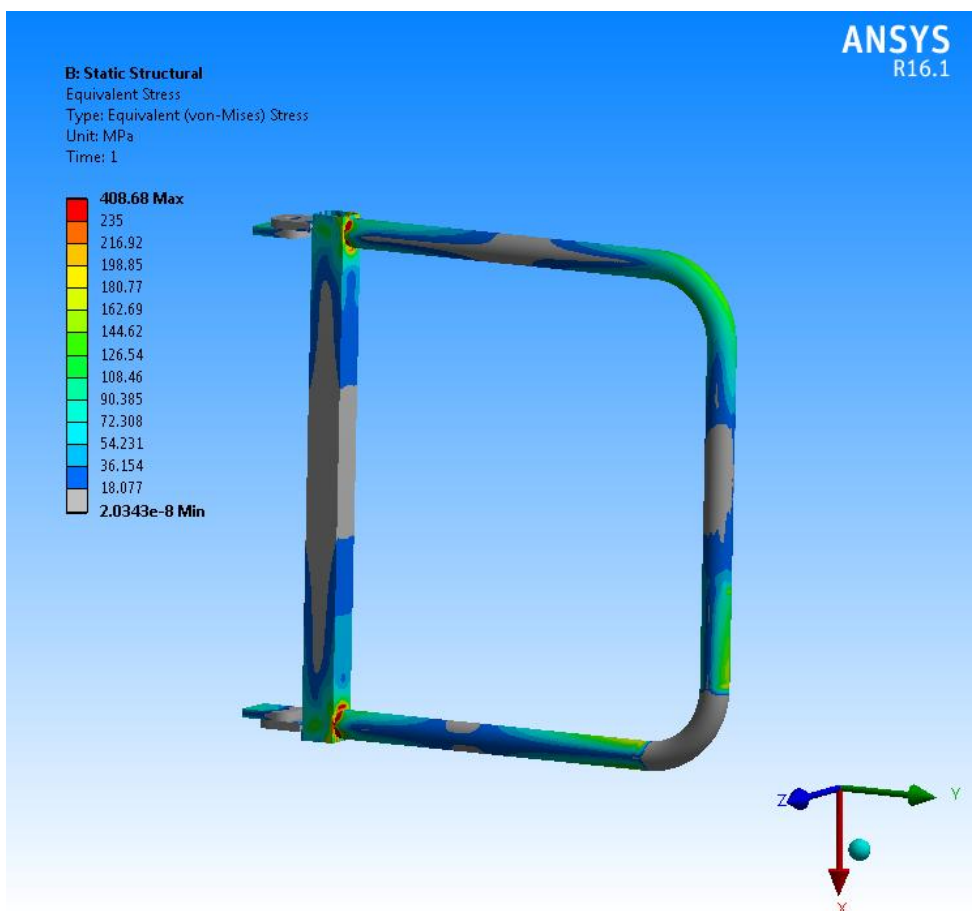

Fig. 9 Equivalent (von-mises) stress in Existing gate

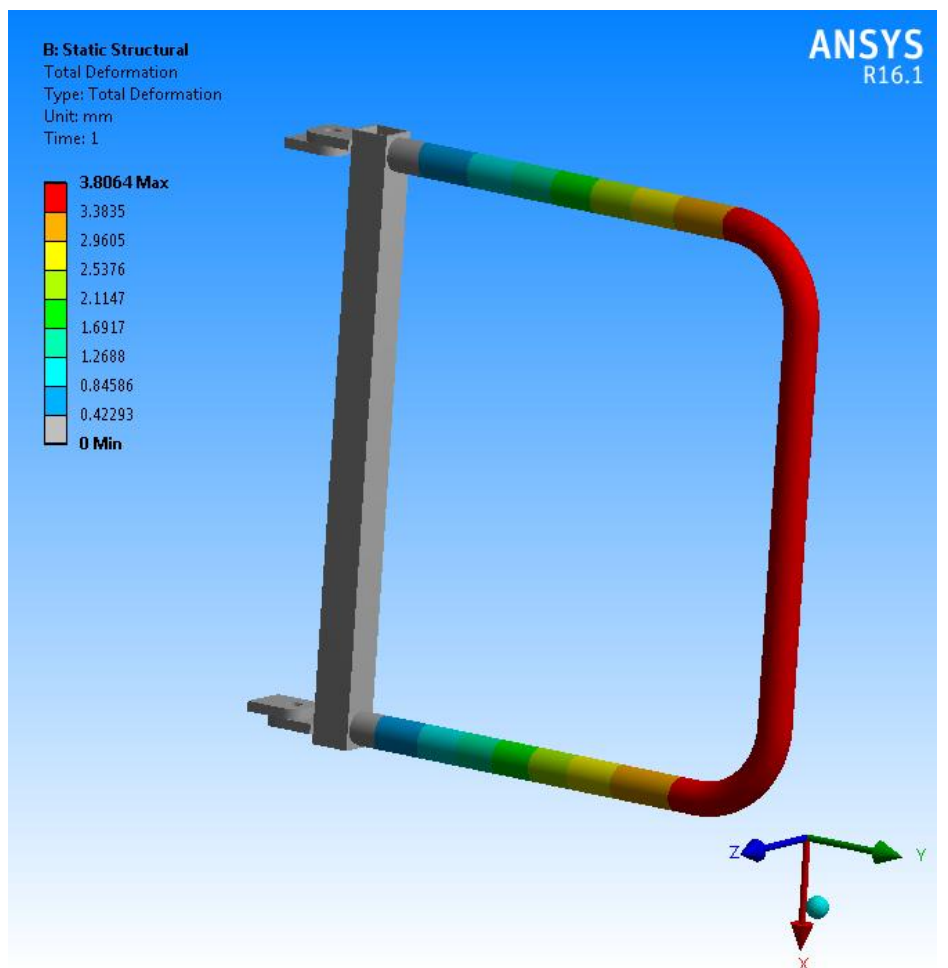

Fig. 10 Total deformation in existing gate

\section{F. Equivalent (von-mises) Stress and total deformation of modified gate structure.}

The fig. 11 shows the stress value of the modified gate. Stress obtained from modified gate is $230 \mathrm{Mpa}$ and fig. 12 shows the deformation of modified gate is $2.7 \mathrm{~mm}$ 


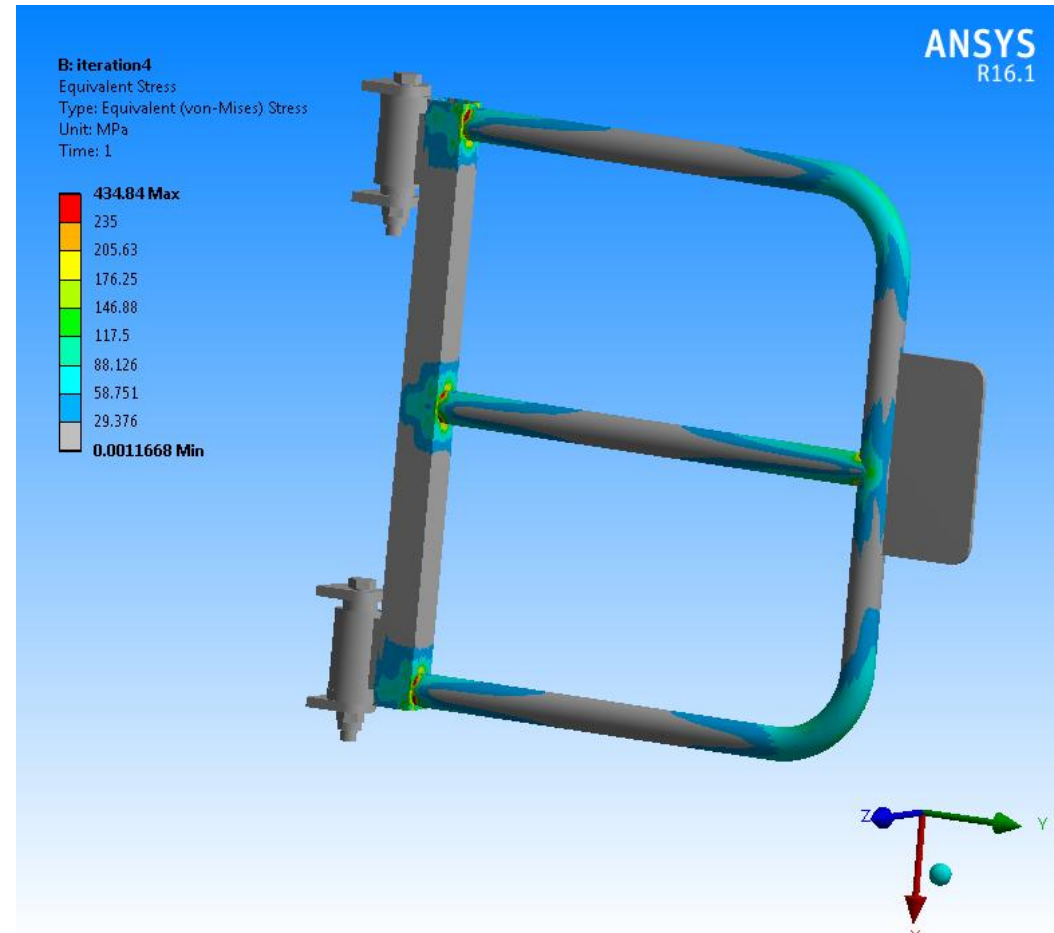

Fig. 11 Equivalent (von-mises) stress in Existing gate

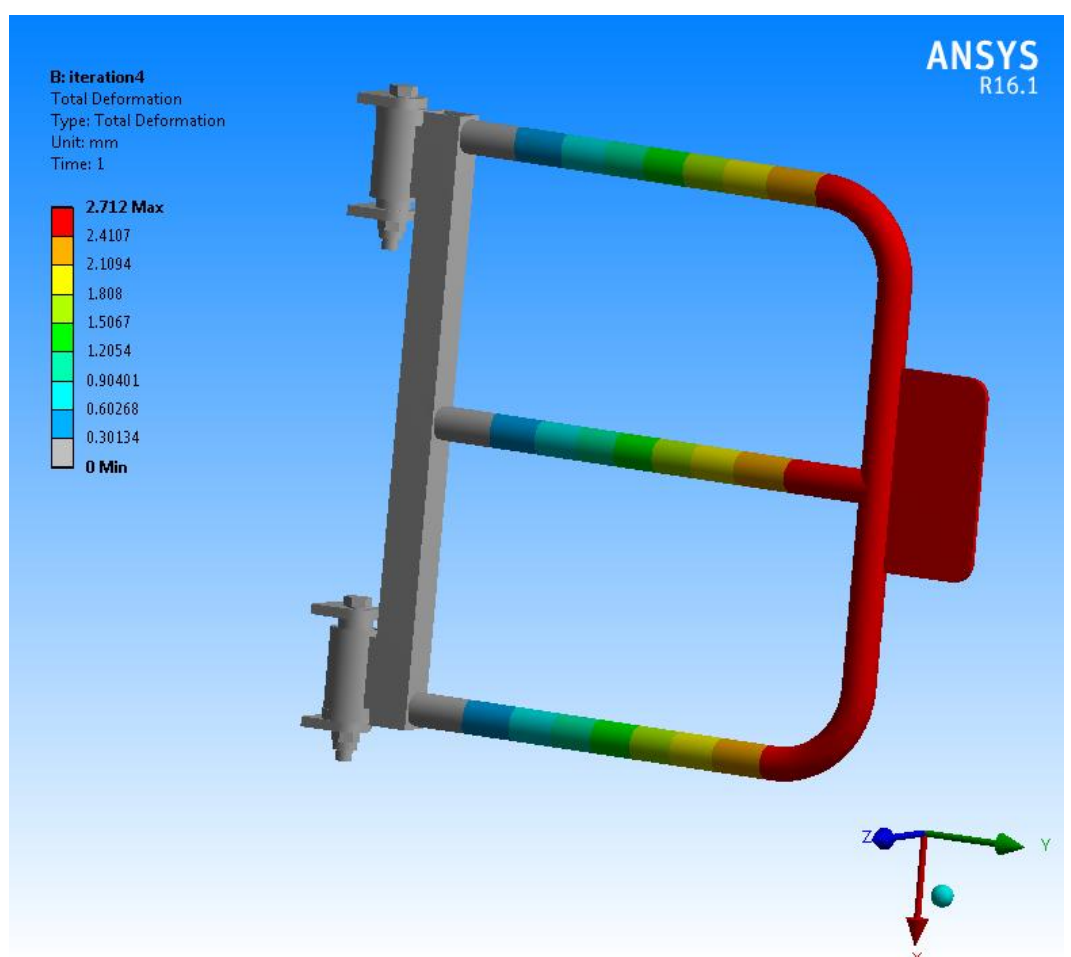

Fig. 12 Total deformation in existing gate

\section{G.Bolt Calculation by Numerical Method:}

As per finite element analysis model has solved in Ansys. As per whole model deflection and stresses are within limit. The stresses are showing below in figure is only coming in bolt.

\section{Stress on Bolt 1:}

The distance of bolt 1 is more hence stress will come more on this bolt. Maximum stress coming on bolt 1 is $7.36 \mathrm{MPa}$. This stress is not more as per our theoretical calculation 


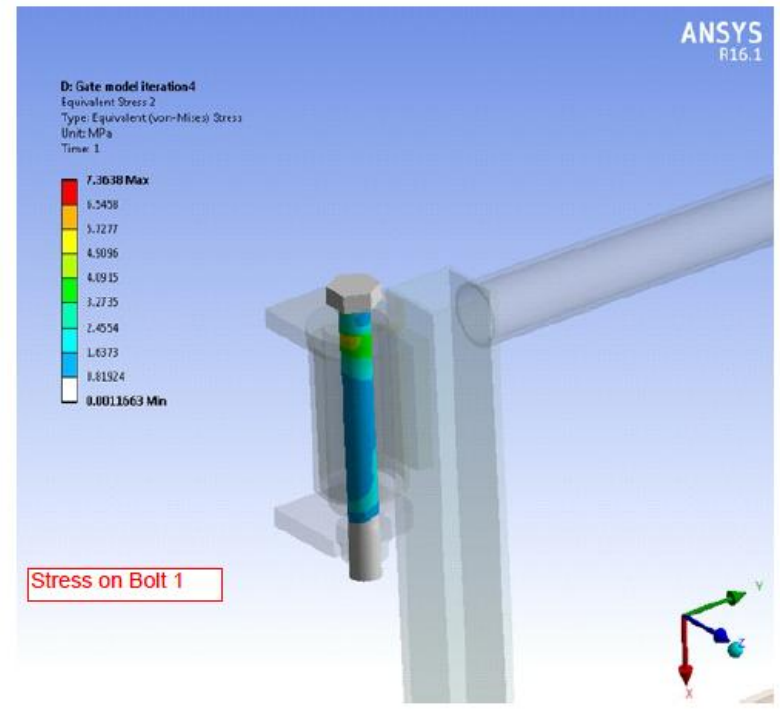

Fig. 13 Equivalent (von-mises) stress in Bolt 1

\section{Stress on Bolt 2:}

The distance of bolt 2 is less hence stress will come less on this bolt. Maximum stress coming on bolt 2 is 4.33 $\mathrm{MPa}$. This stress is not more as per our theoretical calculation.

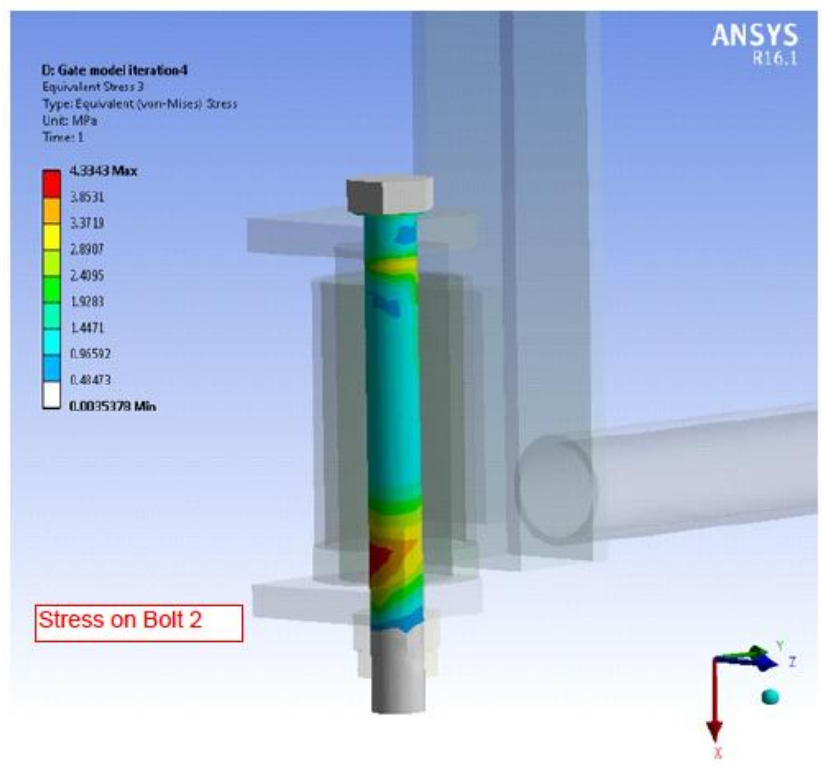

Fig. 14 Equivalent (von-mises) stress in Bolt 2

\section{Comparison of Result for Bolt Calculation:}

As per Analytical calculation for bolt of Gate model it is safe up to $87 \mathrm{MPa}$ stress.

If stress on bolt will come more than $87 \mathrm{MPa}$ then bolt is not safe and we need to change the bolt up to next size As per Finite element analysis maximum stress on bolt is $8 \mathrm{MPa}$. Hence the bolt M16 is safe for this model.

\section{Experimental Analysis}

To verify the deflection values and stiffness of gate experimentally we tested both the gate model on universal testing machine in metallurgical laboratory. The readings from the machine are used to verify with the Finite element analysis results and calculate the stiffness of Gate model and further natural frequency is calculated by using the actual stiffnesscalculated.

In experimentation we find out results on the universal testing machine.Fig. 15 shows the experimental setup of gate. Load is applied on gate by using of load cells of universal testing machine.Fig.16 shows the Gatemodel is placed between load cell and fixture of universal testing machine. Load cell of universal testing 
machine is 2500 N.Load limit is set on the computer also put cross sectional area of gate model to find out the stresses on the peak load. As the load apply on the gate the display of universal testing machine shows the graph of load vs. deformation.

By using this we can find out the deflection of gate at deformation point. We take peak load value for both gate model and take deflection value on that peak load.Deflection values for the Existing gate are $3.6 \mathrm{~mm}$ and Modified Gate model is $2.3 \mathrm{~mm}$.

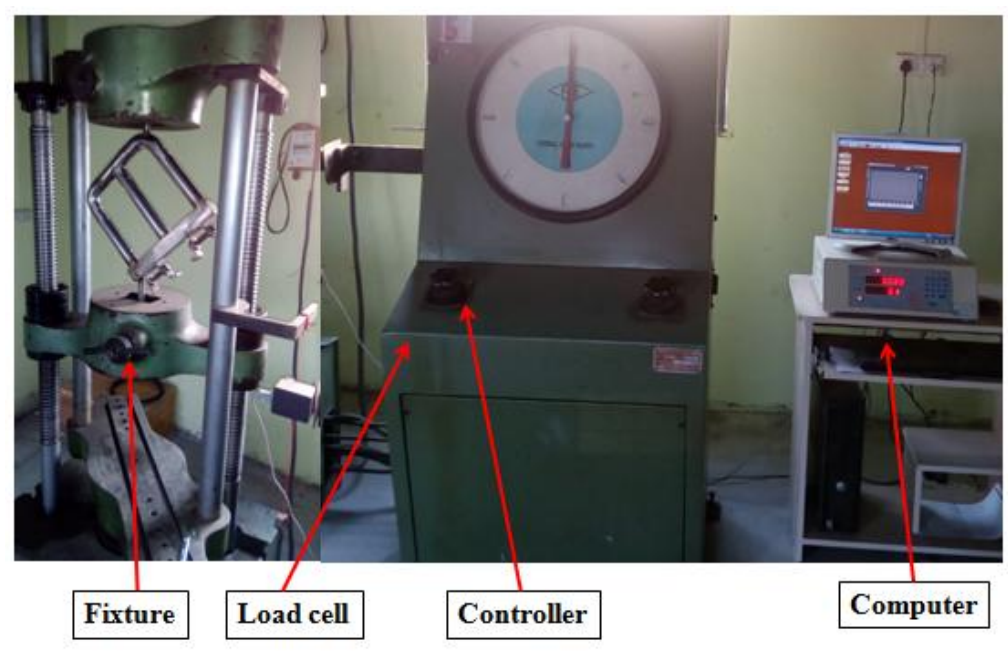

Fig. 15 Experimental setup

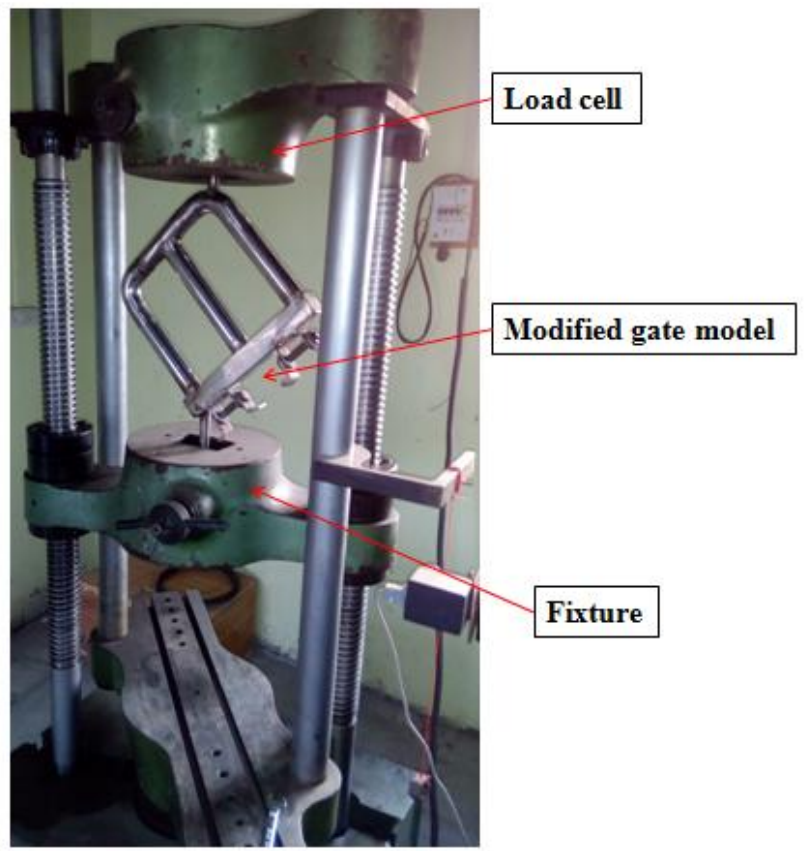

Fig.16Loading on gate by load cell. 


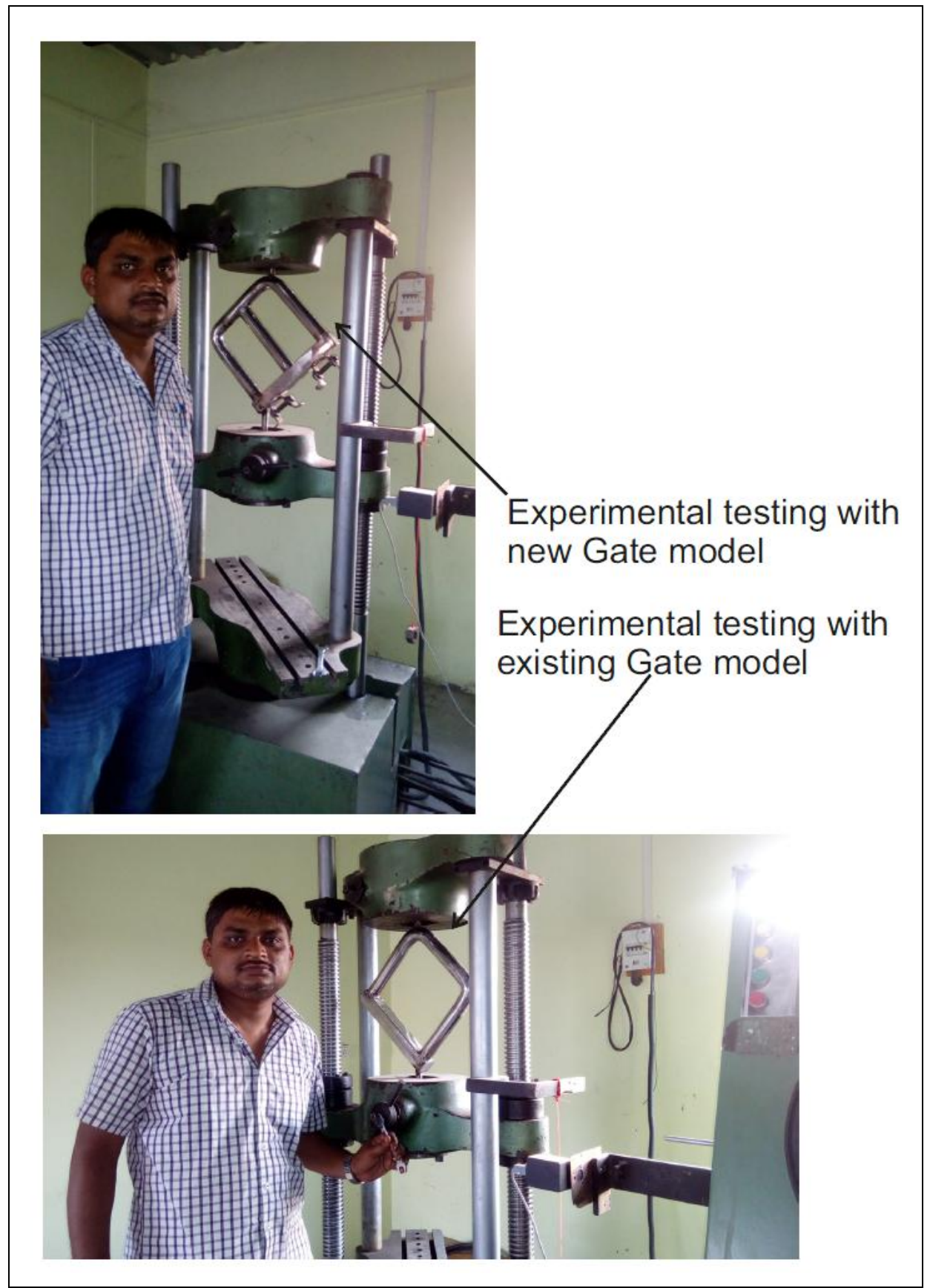

Fig 17: Adjustment of model in the UTM

The deflection value is taken at peak load and this value is compare with our FEA and theoretical results also calculate stiffness for both gates from load vs. Deformation graph. By using stiffness we find out the natural frequency of both model and frequencies of both structure is in the range. Same procedure was applied for both gate models.

\section{A.Experimental results}

From experimentation, we obtain graph of load Vs. deformation of both gate on that graph we also get the peak load value and stress on that load. So this stress was used to analized the results. Fig. $11 \& 12$ shows the graph of load Vs. deformation of Existing and modifiedGate model is respectively. On X axis it shows the deflection( $\mathrm{mm}$ ) values and $\mathrm{Y}$ axis it shows the load (KN) of Gate. 


\section{Results And Discussion}

Static analysis of existing and modified gate is carried out by theoretically, experimentally and Finite element method. By theoreticalcalculation of existing model the deflection is $2.7 \mathrm{~mm}$. By the Finite element method the deflection value is $2.74 \mathrm{~mm}$. By the experimental testing the deflection is $2.3 \mathrm{~mm}$. Hence according to all method the result is matching with all the process.

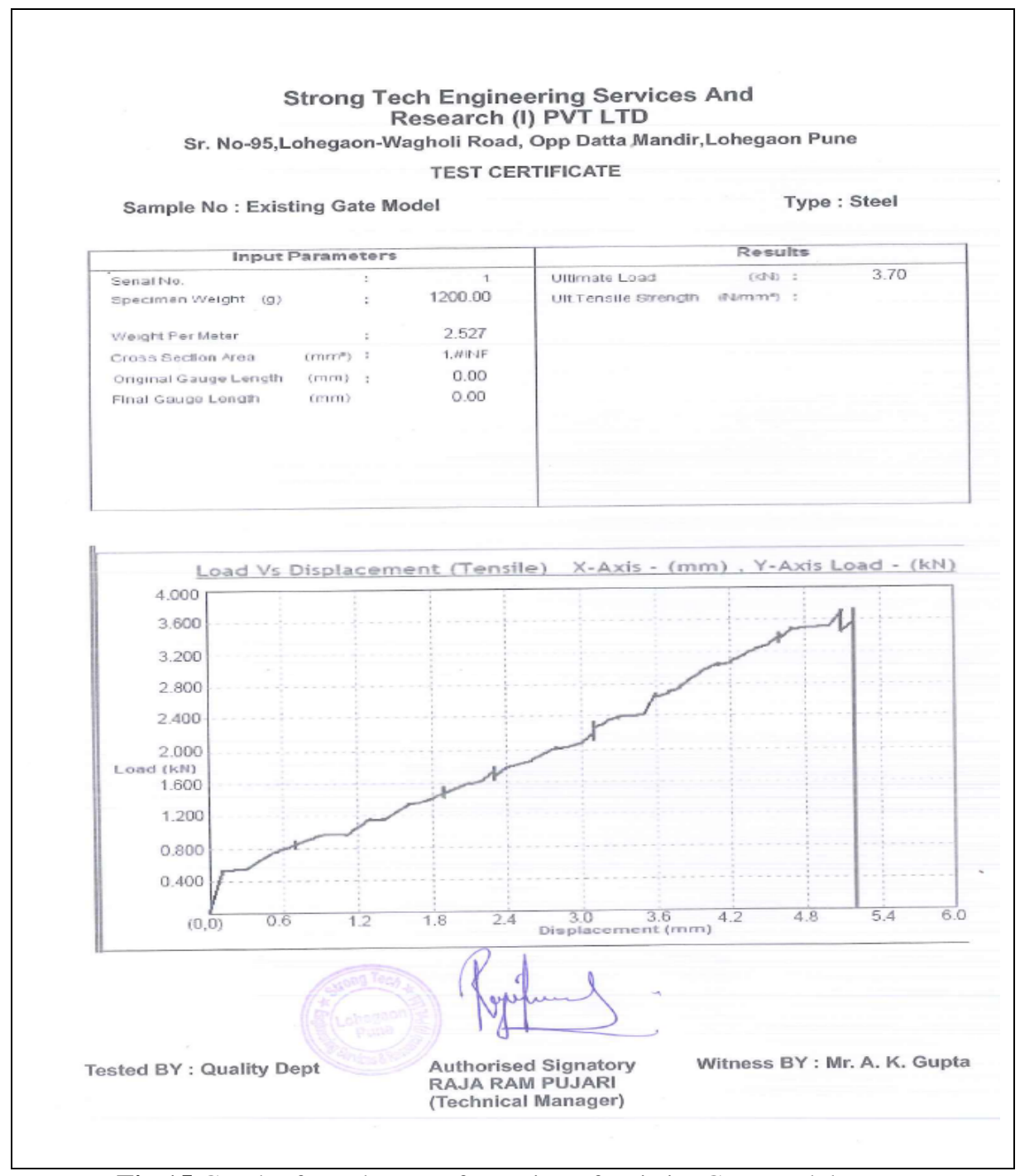

Fig.15 Graph of Load Vs. Deformation of ExistingGate model 


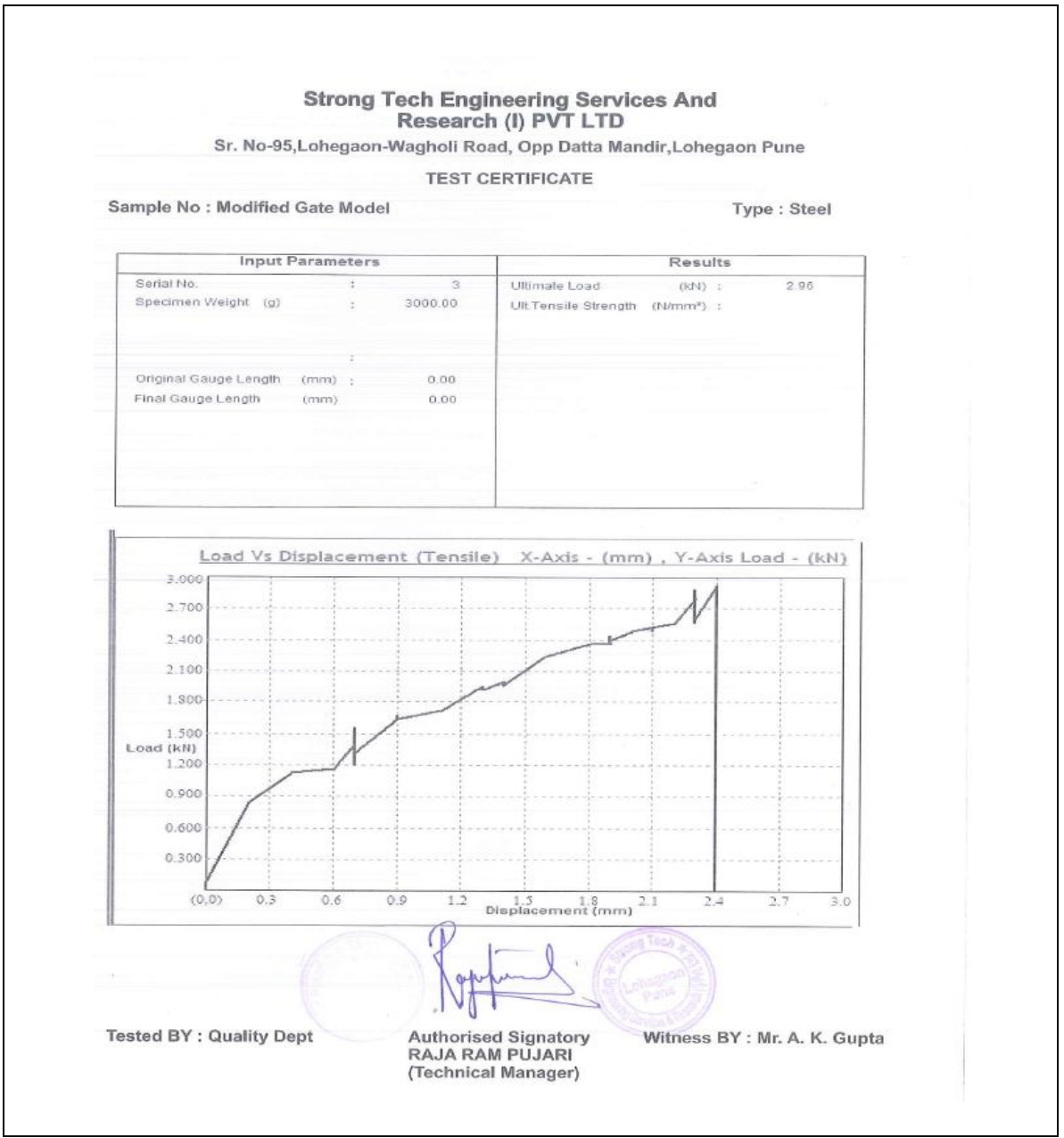

Fig.16 Graph of Load Vs. Deformation of ModifiedGate.

Allowable stress $=$ Yield strength / Factor of safety

$=355 / 1.5$

$=235 \mathrm{MPa}$

So, the calculated stress < allowable stress. i.e. $230 \mathrm{MP}$, our design of modified gate is proved to be safe.

By using FEA method stress values of Existing and modified gate are 260MPaand $230 \mathrm{MPa}$.These values also are in the range. Experimental analysis is also shows the stress values are in range.

Table III Result Analysis

\begin{tabular}{|c|c|c|c|}
\hline \multicolumn{4}{|c|}{ Result Analysis between Existing \& Modified gate } \\
\hline Sr.No & Type of analysis & Existing gate & Modified gate \\
\hline \multicolumn{4}{|c|}{ Theoretical Calculation (For Load-2500N) } \\
\hline 2 & Total deformation & $2.745 \mathrm{~mm}$ & $4.1 \mathrm{~mm}$ \\
\hline \multicolumn{4}{|c|}{ FEA Analysis using ANSYS (For Load-2500N) } \\
\hline 1 & static stress & $230 \mathrm{MPa}$ & $260 \mathrm{MPa}$ \\
\hline 2 & Total deformation & $2.7 \mathrm{~mm}$ & $3.8 \mathrm{~mm}$ \\
\hline \multicolumn{4}{|c|}{ Experimental analysis (Peak load from UTM, For existing and modified modelis $2500 \mathrm{~N}$ ) } \\
\hline 2. & Total deformation & $2.3 \mathrm{~mm}$ & $3.6 \mathrm{~mm}$ \\
\hline
\end{tabular}

Table: Comparison of Deflection Result

\begin{tabular}{|c|l|c|c|}
\hline Sr. No. & \multicolumn{1}{|c|}{ Approach } & \multicolumn{2}{c|}{ Deflection (mm) } \\
\cline { 3 - 4 } & & Existing & Modified \\
\hline 1 & FEA & 3.8 & 2.69 \\
\hline 2 & Theoretical & 4.1 & 2.74 \\
\hline 3 & Experimental & 3.6 & 2.3 \\
\hline \multicolumn{2}{|c|}{$\%$ Error } \\
\hline 4 & Theoretical and Experimental & $8.1 \%$ & $16.0 \%$ \\
\hline 5 & FEA and Experimental & $10.5 \%$ & $14.5 \%$ \\
\hline 6 & Theoretical and FEA & $2.6 \%$ & $1.82 \%$ \\
\hline
\end{tabular}




\section{Conclusion}

As deflection and stress of modified gate model is within the range. Thus, the modified design is safe. This will provide more safety for operators.

There are following important conclusion for this project.

1. As per all the three method of calculation modified model is safe. It will prevent permanent deflection of gate.

2. Load carrying capacity of Modified model is now $250 \mathrm{~kg}$.In comparison with Existing model $40 \%$ load carrying capacity is increased.

3. According to bolt calculation bolt M16 is safe for this model.

4. As per weight comparison, Modified model weight is increase by $20 \%$ with respect to Existing model.

5. This is industry project hence they will consider all the iteration done in project and take final decision.

\section{Acknowledgment}

I take this opportunity to thanks Prof A. B. Gaikwad and Prof. A. N. Patil for valuable guidance and for providing all the necessary facilities, which were indispensable in completion of this work.

\section{References}

[1]. SVENSK STANDARD SS-EN 13001-3-1:2012_1

[2]. $\quad$ ANSYS user manual 16.1.

[3]. American national standard (ANSI/ASSE Z359.14-2014) Safety Requirements.

[4]. Port technology reference.

[5]. Dr.Sadhu Singh.(2011). Theory of Elasticity, 6th ed.Sudha Publication, India.

[6]. S. Ramamurtham, "Strength of Materials"14th Edition, DhanpatRaiPublishingCompany (P) Limited, 2012

[7]. V. B. Bhandari, "Design of Machine Elements" Third Edition, Tata McGraw-Hill Education, 2010.

[8]. A textbook of machine design by P.C.Sharma and D.K.Agarwal, S.K.Kataria and sons, 1998.

[9]. Mechanical engineering design by Joseph E. Shigley, McGraw Hill, 1986.

[10]. A Text Book Of Machine Design, R. S. Khurmi and J. K. Gupta, S. Chand and Co. Ltd.,2005Design Data Hand Book, K. Mahadevan and K. Balaveera Reddy, 3rd Edition.

[11]. Faculty of Mechanical Engineering, "Design Data Book Of Engineers", KalaikathirAchchagam, 2011, 7.110-7.(Book) 